Archimer, archive institutionnelle de l'Ifremer Volume 35, Issue 3, October 2006, Pages 300-313 http://www.ifremer.fr/docelec/ http://dx.doi.org/10.1016/i.aquaeng.2006.04.001

\title{
Production of microalgal concentrates by flocculation and their assessment as aquaculture feeds
}

\author{
Richard M. Knuckey ${ }^{\underline{a}}$, Malcolm R. Brown $\underline{\underline{b}}$, René Robert ${ }^{\underline{c}}$ and Dion M.F. Frampton \\ ${ }^{\mathrm{a}}$ Department of Primary Industries and Fisheries, Northern Fisheries Centre, GPO Box 5396, Cairns, QId 4870, \\ Australia \\ ${ }^{\mathrm{b}} \mathrm{CSIRO}$ Marine Research, GPO Box 1538 Hobart, Tasmania 7001, Australia \\ 'IFREMER, UMR Physiologie et Ecophysiologie des Mollusques Marins Station Expérimentale d'Argenton \\ Presqu'île du Vivier, 29840 Argenton en Landunvez, France \\ *: Corresponding author : Richard.Knuckey@dpi.qld.gov.au
}

\begin{abstract}
A novel technique was developed for the flocculation of marine microalgae commonly used in aquaculture. The process entailed an adjustment of $\mathrm{pH}$ of culture to between 10 and 10.6 using $\mathrm{NaOH}$, followed by addition of a non-ionic polymer Magnafloc LT-25 to a final concentration of $0.5 \mathrm{mg}$ $L-1$. The ensuing flocculate was harvested, and neutralised giving a final concentration factor of between 200- and 800-fold. This process was successfully applied to harvest cells of Chaetoceros calcitrans, C. muelleri, Thalassiosira pseudonana, Attheya septentrionalis, Nitzschia closterium, Skeletonema sp., Tetraselmis suecica and Rhodomonas salina, with efficiencies $\geq 80 \%$. The process was rapid, simple and inexpensive, and relatively cost neutral with increasing volume (cf. concentration by centrifugation). Harvested material was readily disaggregated to single cell suspensions by dilution in seawater and mild agitation. Microscopic examination of the cells showed them to be indistinguishable from corresponding non-flocculated cells. Chlorophyll analysis of concentrates prepared from cultures of $\leq 130 \mathrm{~L}$ showed minimal degradation after 2 weeks storage.
\end{abstract}

Concentrates of T. pseudonana prepared using $\mathrm{pH}$-induced flocculation gave better growth of juvenile Pacific oysters (Crassostrea gigas) than concentrates prepared by ferric flocculation, or centrifuged concentrates using a cream separator or laboratory centrifuge. In follow up experiments, concentrates prepared from $1000 \mathrm{~L}$ Chaetoceros muelleri cultures were effective as supplementary diets to improve the growth of juvenile $\mathrm{C}$. gigas and the scallop Pecten fumatus reared under commercial conditions, though not as effective as the corresponding live algae. The experiments demonstrated a proof-ofconcept for a commercial application of concentrates prepared by flocculation, especially for use at a remote nursery without on-site mass-algal culture facilities.

Keywords: Algal paste; Bivalve; Concentrate; Flocculation; Thalassiosira; Chaetoceros 


\section{Introduction}

Live microalgae have been the traditional food for many larval and juvenile animals in aquaculture. However, their mass cultivation on-site can represent $30 \%$ of a hatchery's operating cost (Coutteau and Sorgeloos, 1992). Alternatives that are potentially more cost-effective have been investigated including microcapsules, dried microalgae, yeasts or yeast-based diets, bacteria and thraustochytrids (Robert and Trintignac, 1997; Knauer and Southgate, 1999; Langdon and Önal, 1999). However, most of these have proved unsuitable as major dietary components because of a lower nutritional value compared to mixtures of microalgae commonly used in aquaculture.

Another alternative that appears to have more potential is algal concentrates (Nell and O'Connor 1991; McCausland et al., 1999; Heasman et al., 2000). For example, centrifuged concentrates of Pavlova lutheri in combination with Chaetoceros calcitrans or Skeletonema costatum gave 85 to $90 \%$ of the growth of a mixed diet of live microalgae for oyster larvae Saccostrea glomerata (Heasman et al., 2000). Commercially, microalgal concentrates could be prepared under two different scenarios. Hatcheries already with the infrastructure for algal mass production could prepare their own concentrates on-site, and thus could limit their algal production to less busy periods of the season, better manage their requirements for microalgae and also reduce costs due to over-production. Alternatively, centralised facilities with greater economies of scale could produce algal concentrates for on-selling to hatcheries.

Though centrifugation has been applied successfully for preparing concentrates, it does have some limitations. First, the process involves exposing cells to high gravitational and shear forces which damage the cell structure. Second, the processing of large culture volumes can be time-consuming and require costly equipment, i.e. a specialised continuous centrifuge. Alternative processes have been developed that are potentially less damaging to cells, including foam fractionation (Csordas and Wang, 2004), flocculation (Millamena et al., 1990; Poelman et al., 1997) and filtration (Rossingol et al., 1999).

Flocculation is the coalescence of finely divided suspended solids into larger loosely packed conglomerates, a process used widely in industry to remove suspended solids, e.g. for clarification of drinking water. In general, the first stage of flocculation is the aggregation of suspended solids into larger particles resulting from the interaction of the flocculant with the surface charge of the suspended solids. The second stage involves the coalescing of aggregates into large flocs that settle out of suspension.

Flocculated algae have previously been used as diets for aquaculture species. Sandbank (1978) fed microalgae grown in waste-water and flocculated with aluminium sulfate to common carp (Cyprinus carpia). A diet containing $25 \%$ algal meal produced growth comparable to the control diet with no harmful effect of the algae or aluminium on the growth rate or health of the fish. Millamena et al. (1990) fed Penaeus monodon larvae dried, flocculated diets of Chaetoceros calcitrans and Tetraselmis chuii. However, a disadvantage of many published processes for flocculating algae is that the harvested cells are difficult to disaggregate back to single cells, which is a requirement for feeding them to filter-feeding species such as bivalves.

In this study, we investigated the flocculation and de-flocculation of microalgae with broad application within the aquaculture industry. Initially, three species of microalgae were investigated using a ferric ion induced flocculation process. Subsequently, ten species of microalgae from five classes were investigated using a 
novel $\mathrm{pH}$-induced flocculation process. This increase in species selection is a reflection of the merits of $\mathrm{pH}$-induced flocculation over the ferric method. We then tested algal concentrates of Thalassiosira pseudonana and Chaetoceros muelleri prepared using this process in feeding experiments with juvenile bivalves.

\section{Materials and methods}

\subsection{Microalgal cultures}

Microalgae from five algal classes were assessed for their ability to be concentrated by flocculation (Table 1). Cultures of $1.5 \mathrm{~L}$ (2 L Erlenmeyer flask) to $20 \mathrm{~L}$ (polycarbonate carboy) were grown using $\mathrm{f} / 2$ medium or $\mathrm{F}$ medium for the cryptophyte species (Guillard and Ryther, 1962) at $20 \pm 2{ }^{\circ} \mathrm{C}$ and mixed with $0.2 \mu \mathrm{m}$ filtered air enriched with $1 \% \mathrm{CO}_{2}$. Cultures were grown under continuous illumination (120 or 200 $\mu \mathrm{mol}$ photons PAR $\mathrm{m}^{-2} \mathrm{~s}^{-1}$, respectively for 1.5 and $10-20 \mathrm{~L}$ ) and harvested during late logarithmic growth phase.

Larger volume cultures (100 to $1000 \mathrm{~L})$ were grown in polyethylene bags, a polycarbonate tank or open fibreglass tanks. Culture conditions were similar to $10 \mathrm{~L}$ cultures, using $\mathrm{f} / 2$ medium. Temperature was partially regulated by air-conditioning (unless otherwise specified, at $20 \pm 2^{\circ} \mathrm{C}$ ) and illumination was provided by cool white fluorescent lights, either continuously or 12:12 h L:D cycle. Metal halide lamps illuminated tank cultures (500 to $1000 \mathrm{~L}$ ).

\subsection{Ferric induced flocculation and deflocculation}

Initial flocculation experiments with Thalassiosira pseudonana were to define the optimum $\mathrm{Fe}^{3+}$ concentration (between 0 to $1 \mathrm{mM}$ ) for ferric-induced flocculation. They were conducted in $250 \mathrm{~mL}$ beakers using a magnetic stirrer for mixing. For larger scale (10 to $500 \mathrm{~L})$ flocculation, cultures were mixed by aeration. For beaker experiments, stock solutions of $\mathrm{FeCl}_{3} \cdot 6 \mathrm{H}_{2} \mathrm{O}(0.1 \mathrm{M})$ and polyelectrolyte $(0.05 \% \mathrm{LT}-25$, CIBA Specialty Chemicals, Wyong, NSW, Australia) were diluted 1:5-1:10 with $0.01 \mathrm{M} \mathrm{HCl}$ and 1:10 with deionised water respectively. For flocculation of larger volumes, the stock solutions were used undiluted.

The $\mathrm{FeCl}_{3} \cdot 6 \mathrm{H}_{2} \mathrm{O}$ was added slowly (e.g. 5 to $10 \mathrm{~s}$ for $250 \mathrm{~mL}$ assays; $\sim 5 \mathrm{~min}$ for $500 \mathrm{~L}$ cultures) to the zone of maximal mixing. Mixing was continued until small flocs were visible, then the polyelectrolyte was added $\left[0.5 \mathrm{mg} \mathrm{L}^{-1}\right]$ and the mixing reduced. When large flocs formed ( $\sim 1 \mathrm{~min})$ the mixing was stopped and the flocs allowed to settle under gravity. Surface water was then siphoned off and the settled floc collected and stored at $4^{\circ} \mathrm{C}$. After $24 \mathrm{~h}$ at $4^{\circ} \mathrm{C}$ the floc settled further and the supernatant was again removed.

Ferric flocs could be de-flocculated using $\mathrm{Na}_{2}$-EDTA. First, the iron content of a subsample of the floc was measured using a colorimetric assay measuring iron as the red complex formed between $\mathrm{Fe}^{2+}$ and 1,10 ortho-phenanthroline (Vogel, 1978). Based on the iron analysis, a $0.2 \mathrm{M} \mathrm{Na}_{2}$-EDTA solution ( $\mathrm{pH} \mathrm{4.5)}$ was then added to the bulk floc on an equal molar basis. The floc was mixed for $5 \mathrm{~min}$ before being centrifuged (170 g, $5 \mathrm{~min})$ to recover cells. The yellow, iron-rich supernatant was discarded and the collected cells resuspended in sterile seawater. 


\section{3. $\quad p H$-induced flocculation and de-flocculation}

Initial experiments to flocculate Thalassiosira pseudonana were conducted in $250 \mathrm{~mL}$ beakers using a magnetic stirrer for mixing. Stock solutions of $\mathrm{NaOH}(1 \mathrm{M})$ and polyelectrolyte $(0.05 \%$ LT-25) used to flocculate algal cultures were diluted 1:5-1:10 with deionised water. With larger volumes (e.g. 10 to $500 \mathrm{~L}$ cultures), the $\mathrm{NaOH}$ stock solution was diluted 1:2 with potable water and the polyelectrolyte used undiluted.

The $\mathrm{NaOH}$ was added to the point of maximal mixing at a rate so that there was a steady increase in culture $\mathrm{pH}$ : e.g. for $250 \mathrm{~mL}$ volumes this took 5 to $10 \mathrm{~s}$; for $500 \mathrm{~L}$, 5 to $10 \mathrm{~min}$. Between $\mathrm{pH} 10.0$ and 10.6 (i.e. after addition of $\mathrm{NaOH}$ to 6 to $12 \mathrm{mM}$ final concentration), there was a shift in the clarity of the culture as a white precipitate formed. At this stage, $\mathrm{NaOH}$ addition ceased, mixing was reduced and the polyelectrolyte was added to give a final concentration of $0.5 \mathrm{mg} \mathrm{L}^{-1}$. When large flocs formed $(\sim 1 \mathrm{~min})$ the mixing was stopped and the flocs allowed to settle under gravity (10 to $20 \mathrm{~min}$ ). Surface water was then siphoned off and the floc collected. The suspension was deflocculated immediately by adjusting the $\mathrm{pH}$ of the floc slurry to $\mathrm{pH}$ 7.5 to 8.0 using concentrated $\mathrm{HCl}$, with mixing. The floc slurry darkened as the bulk of the white precipitate dissolved leaving small $(<1 \mathrm{~mm})$ aggregates of densely-packed cells. These were settled overnight at $4^{\circ} \mathrm{C}$ and any supernatant was removed. Harvested material was readily disaggregated to single cell suspensions by dilution in seawater and mild agitation.

\subsection{Measurement of flocculation efficiency and volume}

In the $250 \mathrm{~mL}$ trials, flocculation efficiency was measured by comparing the residual chlorophyll $a$ concentration to that of the initial culture. A $50 \mathrm{~mL}$ aliquot of flocculated culture was centrifuged ( $10 \mathrm{~g}, 2 \mathrm{~min})$ to sediment flocculated cells while leaving non-flocculated cells in the supernatant. The supernatant was recovered and an aliquot taken to measure chlorophyll $a$, efficiency was then determined by comparison to the chlorophyll concentration of the pre-flocculated culture. To measure flocculation efficiency in larger volumes, chlorophyll $a$ was measured in an aliquot of the supernatant after gravity settlement of the floc. When flocculating with ferric chloride, an aliquot of the supernatant and flocculated cells was also taken to measure the partition of the iron. The floc pellets from the entire $250 \mathrm{~mL}$ volume $(5 \mathrm{x} 50 \mathrm{~mL}, 10 \mathrm{~g}, 2$ $\mathrm{min}$ ) were combined in a graduated $10 \mathrm{~mL}$ glass tube and centrifuged ( $670 \mathrm{~g}, 3 \mathrm{~min})$ to measure packed floc volume. An aliquot of the combined supernatants and the resuspended ferric floc pellet was taken to measure the ferric concentration.

\subsection{Chemical analysis}

Microalgal samples were filtered under vacuum through Whatman GF/C $25 \mathrm{~mm}$ glass-fibre filters (eg. for 1-2 mg algal dry weight (DW)) or $47 \mathrm{~mm}$ filters (eg. for 10 to $20 \mathrm{mg} \mathrm{DW}$ ). Filters were stored at $\leq-20^{\circ} \mathrm{C}$ and analysed within 6 months.

Daily, filtered samples of algae used as oyster diets in the preliminary experiment were combined into grouped samples that represented three, weekly periods. These combined algal samples were firstly extracted using a method adapted from Kochert, (1978) and Whyte, (1987) to form four fractions (protein, lipid, polysaccharide and mono- and oligosaccharides) which were then analysed 
individually. Filtered algal samples were placed in $10 \mathrm{~mL}$ Maxi-vials (Alltech Associates). The filters were then extracted for lipid by repeated extraction with chloroform-methanol $(2: 1, \mathrm{v} / \mathrm{v} ; 17 \mathrm{~mL}$ total $)$ then chloroform-methanol-water $(2: 4: 1$, $\mathrm{v} / \mathrm{v} / \mathrm{v} ; 2$ x $4 \mathrm{~mL}$ ) (Kochert, 1978; Whyte, 1987). The solvent ratio of chloroformmethanol-water in the combined supernatants was adjusted to 1:1:0.9 (v/v) to enable phase separation. The chloroform phase was evaporated under vacuum and the residual lipid weighed. The methanol-water phase, left after collection of the chloroform-lipid phase, contained mono- and oligosaccharides and was concentrated under vacuum at $60^{\circ} \mathrm{C}$ to $10 \mathrm{~mL}$ and analysed for carbohydrate by the phenol-sulphuric acid method (Dubois et al., 1956). The lipid-free residue left in the Maxi-vial was solubilised by repeated $(3 \times 5 \mathrm{~mL}) 10$ min extractions at $100^{\circ} \mathrm{C}$ with $1 \mathrm{M} \mathrm{NaOH}$. Combined extracts were diluted to $25 \mathrm{~mL}$ with distilled water and subsamples analysed directly for carbohydrate (polysaccharide fraction) and after adjustment of $\mathrm{pH}$ to 8-9 for protein by a modified Lowry et al. (1951) method (Clayton et al., 1988).

Chlorophyll $a$ within algal samples (pellets, or cells retained on filters) was extracted with $90 \%$ acetone and determined spectrophotometrically using the equations of Jeffrey and Humphrey (1975). Ascorbic acid in samples was determined by HPLC with fluorometric detection (Brown and Miller, 1992).

Iron was measured using a colorimetric method adapted from Vogel (1978). The sample was adjusted to $\mathrm{pH}$ 0.8-1.0 using concentrated $\mathrm{HCl}$ then filtered through a glassfibre $(\mathrm{GF} / \mathrm{C})$ filter or centrifuged. Dependent on iron concentration, the samples were diluted in $0.01 \mathrm{M} \mathrm{HCl}$ (working range 10 to $300 \mu \mathrm{M} \mathrm{Fe}^{3+}$ ). For assay blank and duplicate standards, $5.0 \mathrm{~mL}$ deionised water was pipetted into $3 \times 15 \mathrm{~mL}$ glass test tubes. For test sample, 3 x $5.0 \mathrm{~mL}$ aliquots were pipetted into glass test tubes. These represented duplicate sample assays and a standard addition to confirm no interference from the sample media. To the duplicate standards and the sample standard addition tube, $100 \mu \mathrm{l}$ of iron standard $\left(5 \mathrm{mM} \mathrm{FeCl} 3 \cdot 6 \mathrm{H}_{2} \mathrm{O}\right.$ in $\left.0.01 \mathrm{M} \mathrm{HCl}\right)$ was added and the samples mixed. To all tubes, $4 \mathrm{~mL} \mathrm{10 \%} \mathrm{(w/v)} \mathrm{hydroxylamine} \mathrm{hydrochloride} \mathrm{solution}$ was added and then $1 \mathrm{~mL}$ of $2 \mathrm{M}$ acetate buffer ( $\mathrm{pH} 4.0$ ) followed by $4 \mathrm{~mL}$ of phenanthroline solution $(0.25 \% \mathrm{w} / \mathrm{v})$. Samples were mixed, left for at least 10 minutes at room temperature, remixed, then their absorbance measured at $508 \mathrm{~nm}$ against the assay blank.

The average standard absorbance of all the standards and standard addition tubes was calculated and the total iron concentration determined from the formula:

$$
\text { Fe concentration }(\mu \mathrm{M})=\frac{\text { Sample Absorbance } \mathrm{x} 100 \times \text { Dilution Factor }}{\text { Average Absorbance of Standards }}
$$

For dry weight (DW) and ash free dry weight (AFDW) determination, algal samples (eg. 10 to $20 \mathrm{mg} \mathrm{DW}$ ) were filtered through pre-combusted $\left(450^{\circ} \mathrm{C} ; 24 \mathrm{~h}\right)$, pre-weighed, $47 \mathrm{~mm}$ filters and then rinsed with $30 \mathrm{~mL}$ of $0.5 \mathrm{M}$ ammonium formate. Filters were dried overnight $\left(80^{\circ} \mathrm{C}\right)$ then reweighed to determine DW. They were then combusted in a muffle furnace $\left(450^{\circ} \mathrm{C} ; 24 \mathrm{~h}\right)$ and reweighed to determine ash and AFDW. For similar analysis of animals, sub-samples were collected at commencement, during and completion of feeding experiments. Sub-samples were rinsed $(3 \times 10 \mathrm{~mL})$ in deionised water, transferred onto pre-combusted, pre-weighed aluminium foil and dried at $100^{\circ} \mathrm{C}$ 
for $48 \mathrm{~h}$ before being weighed to determine DW. The samples were then combusted in a muffle furnace $\left(450{ }^{\circ} \mathrm{C} ; 24 \mathrm{~h}\right)$, and re-weighed to determine AFDW. For the preliminary experiment, $1 \mathrm{~mL}$ volumes of juvenile oysters were used per replicate and an additional five $1 \mathrm{~mL}$ samples were taken for determination of initial DW and AFDW. After determination of the DW of the 5 samples, each sample was approximately split into quarters and the first 50 oysters from one of the quarters were removed and weighed to determine the average individual oyster DW then combusted for determination of AFDW. The DW of each group of 50 oysters was compared to that of its initial $1 \mathrm{~mL}$ sample to obtain an estimate of the average number of oysters added per experimental replicate.

\subsection{Thalassiosira pseudonana concentrates as bivalve feeds - preliminary experiment}

Flocculated concentrates of Thalassiosira pseudonana were compared to centrifuged concentrates and live cultures of the same alga as food for juvenile Pacific oysters (Crassostrea gigas). The oysters were provided by Shellfish Culture Ltd. (Clifton Beach, Tasmania, Australia). Oysters were cultured in $10 \mathrm{~L}$ buckets containing $8 \mathrm{~L}$ of $0.6 \mu \mathrm{m}$ filtered seawater and retained within mesh-screened chambers (Brown et al., 1998). Each mesh-screened chamber contained $1 \mathrm{~mL}$ of freshly graded $(1500 \mu \mathrm{m})$, juvenile oysters. Oysters were dispensed from a graduated, conical bottom, glass centrifuge tube. The centrifuge tube was filled with seawater and oysters gradually added with intermittent, gentle vibration until a settled oyster volume of $1 \mathrm{~mL}$ was achieved. Using this method the average number of oysters per chamber was $371 \pm 10$ with an average individual DW and AFDW of $1.22 \mathrm{mg}$ and $93 \mu \mathrm{g}$, respectively. Water was recirculated within each bucket using an aquarium pump (Aquarium Power Head 480, Second Nature, NJ, USA). Oysters were acclimatised for two days before feeding, according to the following dietary treatments (4 replicates each):

1) no added algae (control),

2) live algae (i.e. T. pseudonana),

3) algae centrifuged using a laboratory centrifuge,

4) algae centrifuged using a cream separator

5) ferric flocculated concentrate, and

6) $\mathrm{pH}$-flocculated concentrate

Algal diets were prepared from multiple, late logarithmic $\left(2-4 \times 10^{6}\right.$ cells $\left.\mathrm{mL}^{-1}\right)$ $10 \mathrm{~L}$ cultures, and were added at a rate of $10 \mathrm{mg} \mathrm{DW}^{\text {bucket }}{ }^{-1} \mathrm{~d}^{-1}$. Concentrates were 0.5 to 1 week old at the commencement of the oyster feeding and, together with the live algae, were biochemically analysed throughout the experiment. The laboratorycentrifuged concentrate was prepared using a Sorvall RT6000 (1500 g, $10 \mathrm{~min}$ ). For the cream separator concentrate, the culture was centrifuged using an Alfa Laval 106AE unit (DeLaval, Tumba, Sweden) at a flow rate of $0.9 \mathrm{~L} \mathrm{~min}^{-1}$. For ferric flocculation the culture $\mathrm{pH}$ was raised to $\mathrm{pH} 9.5$ and $\mathrm{Fe}^{3+}$ was adjusted to $230 \mu \mathrm{M}$. Polyelectrolyte $\left(0.05 \%\right.$ LT-25) was added $\left(1 \mathrm{~mL} \mathrm{~L}^{-1}\right)$ and the flocs left to settle overnight at $4{ }^{\circ} \mathrm{C}$, then collected. The $\mathrm{pH}$ flocculation was induced by addition of $0.5 \mathrm{M} \mathrm{NaOH}$ to culture to give a final $[\mathrm{NaOH}]$ of $7 \mathrm{mM}$. Polyelectrolyte $(0.05 \% \mathrm{LT}-25)$ was then added $\left(1 \mathrm{~mL} \mathrm{~L}^{-}\right.$ ${ }^{1}$ ) and settled flocs were neutralised, transferred to a measuring cylinder and allowed to settle further overnight at $4^{\circ} \mathrm{C}$, then collected. The algal concentrate produced using the 
cream separator was a thick paste with a moisture and DW concentration of $82 \%$ and $128 \mathrm{~g} \mathrm{~L}^{-1}$, respectively. Cells were concentrated approximately 2000 fold to a density of $10^{9}$ cells $\mathrm{mL}^{-1}$. Concentrates produced using the laboratory Sorvall centrifuge or by flocculation were liquid concentrates. These had cell densities of approximately 100 times that of the initial culture and a DW concentration of between 6 and $7 \mathrm{~g} \mathrm{~L}^{-1}$. All concentrates were stored in sealed plastic tubes in the dark at $4{ }^{\circ} \mathrm{C}$.

Oysters, buckets and chambers were cleaned daily with a fine spray of $0.6 \mu \mathrm{m}$ filtered seawater and refilled with filtered seawater maintained at 18 to $20^{\circ} \mathrm{C}$. On day 8 , 15 and at completion of the experiment on day 22, sub-samples of 50 oysters were removed from each replicate for determination of DW and AFDW. Oysters were distributed over the screen of the chamber and then approximately divided into quarters. From one of the quarters, the first 50 oysters were removed and then the remainder of the population was redistributed over the screen surface. Oyster growth rates were determined from measurement of the initial and final DW and AFDW to give an instantaneous growth rate $(\mathrm{k})$ in $\mathrm{d}^{-1}$ :

$$
\mathrm{k}=\left(\ln \mathrm{W}_{\mathrm{f}}-\ln \mathrm{W}_{\mathrm{i}}\right) / \mathrm{t}
$$

where, $\mathrm{W}_{\mathrm{f}}$ and $\mathrm{W}_{\mathrm{i}}$ refer to final and initial oyster weights and $\mathrm{t}=$ duration of the experiment in days.

\subsection{Assessment of $\mathrm{pH}$-flocculated algal concentrates as bivalve feeds - commercial rearing}

Two follow-up experiments assessed the nutritional value of flocculated concentrates under commercial rearing conditions. In Experiment $1, \approx 14,000$ juvenile Pacific oysters (1100 $\mu \mathrm{m}$; average $735 \mu \mathrm{g}$ DW, $90 \mu \mathrm{g}$ AFDW) were stocked into each of the same buckets used in the preliminary experiment, except they were operated as upwellers by using a flow-through mode (McCausland et al., 1999). Hence, 50- $\mu \mathrm{m}$ filtered seawater from Shellfish Culture's Pipe Clay Lagoon hatchery (30 km southeast of Hobart, Australia) was pumped continuously through each upweller at 700 to 800 $\mathrm{mL} \mathrm{min}^{-1}$. One treatment group of oysters received no additional food (i.e. control, or non-supplemented). The other three treatments were supplemented daily with $200 \mathrm{mg}$ DW.upweller ${ }^{-1}$ of a) concentrated Chaetoceros muelleri, b) live C. muelleri and c) live C. calcitrans. There were three replicates per treatment.

For the supplementary diets, live algal cultures were maintained semicontinuously at late log phase in 10 and 20 L carboys. Algal concentrates were prepared on three occasions from open, $1000 \mathrm{~L}$ tank cultures of $C$. muelleri grown at the industry hatchery site $(300 \mathrm{~km}$ from the experiment site). Cultures were grown under continuous illumination (metal halide lamps) at $25 \pm 5^{\circ} \mathrm{C}$, mixed with filtered air in $\mathrm{f} / 2$ media, and harvested at late logarithmic growth phase. Concentrates of the algae were prepared by $\mathrm{pH}$ flocculation and transported in carboys on ice to the CSIRO laboratory within $3 \mathrm{~h}$. Concentrates were thereafter stored at $4^{\circ} \mathrm{C}$, and the average age of concentrates when used was $10 \pm 4$ days. For delivering the supplementary food, rations of the algae were transferred daily to $20 \mathrm{~L}$ plastic buckets, which were then filled with seawater. Algal food from each bucket was pumped through silicon tubing using a peristaltic pump to each of the respective treatment replicates. Throughout the experiment, samples $(n \geq 5)$ of live and concentrated algae, and seawater from Pipe Clay Lagoon were filtered 
through glass fibre filters and retained at $-80^{\circ} \mathrm{C}$ for 1 to 4 weeks, for subsequent biochemical assays (Brown and Miller, 1992; McCausland et al., 1999).

Average daily minimum and maximum water temperatures within upwellers were 14.3 and $17.0^{\circ} \mathrm{C}$, respectively. Chambers and the retained oysters were removed from upwellers for a maximum of 20 mins daily, and cleaned with a fine spray of freshwater to remove faeces and other particles. The experiment was terminated after $25 \mathrm{~d}$.

In Experiment 2, 140 individual juvenile hatchery-reared scallops Pecten fumatus (3-4 mm; average $5.1 \mathrm{mg}$ DW and $0.62 \mathrm{mg}$ AFDW) were stocked into the same upwellers as those used in Experiment 1 and distributed among the same treatments. Methods for the maintenance of animals and the production and delivery of the algal feeds were also identical, except the filtered seawater ( $50 \mu \mathrm{m}$ nominal) from Pipe Clay Lagoon was pumped continuously through each upweller at $1 \mathrm{~L} \mathrm{~min}^{-1}$. Also, care was taken to ensure the scallops remained completely submerged in seawater during the daily cleaning process. Average daily minimum and maximum water temperatures within upwellers were 16.9 and $19.1^{\circ} \mathrm{C}$, respectively. Average age of concentrates when used was $8 \pm 4$ days. The experiment was terminated after $14 \mathrm{~d}$.

Subsamples of bivalves were collected from each treatment at the beginning and end of both experiments for DW analysis. Growth rates were analysed by ANOVA. Differences between treatments were compared using Fisher's protected least significant difference (PLSD) test for pairwise comparisons. Survival was estimated by counting the proportion of dead animals (assessed visually as those that were severely gaping) at the beginning and end of the experiment.

\section{Results}

\subsection{Ferric-induced flocculation and deflocculation}

The main effect of flocculating with increasing $\mathrm{Fe}^{3+}$ concentrations was a corresponding increase in the mass of the formed floc. Over the $\mathrm{Fe}^{3+}$ dose range of 0 to $1000 \mu \mathrm{M}$, the volume of formed floc ( $\mathrm{F}_{\mathrm{V}}$; in $\mathrm{mL}$ for $250 \mathrm{~mL}$ assay) increased linearly according to the equation:

$\mathrm{F}_{\mathrm{V}}=0.0012\left[\mathrm{Fe}^{3+}\right] ; \quad \mathrm{r}^{2}=0.98 ; \mathrm{P}<0.05$

Where $\left[\mathrm{Fe}^{3+}\right]$ was the final $\mu \mathrm{M}$ ferric concentration.

Flocculation efficiency of Thalassiosira pseudonana cells increased in an exponential relationship to increasing $\mathrm{Fe}^{3+}$ concentration, reaching an asymptote of $97 \%$ at $1000 \mu \mathrm{M}$ (Fig. 2). Addition of low concentrations of 62.5 and $125 \mu \mathrm{M} \mathrm{Fe}^{+3}$ resulted in inefficient and highly variable flocculation with efficiencies $(\% \pm 1 \mathrm{SD})$ of $29 \pm 34$ and $54 \pm 33$, respectively. At the higher concentrations of 500 and $1000 \mu \mathrm{M}$ $\mathrm{Fe}^{+3}$, flocculation was efficient and predictable with efficiencies of $96 \pm 1$ and $93 \pm 7$, respectively. However, at these higher concentrations the formed flocs contained significantly more iron (and less algae) per unit of floc than those produced using 250 $\mu \mathrm{M} \mathrm{Fe}^{+3}$. At $250 \mu \mathrm{M} \mathrm{Fe}^{3+}$ flocs contained $2 \times 10^{7}$ cells $/ \mu$ mole $\mathrm{Fe}^{3+}$, whereas at 500 and $1000 \mu \mathrm{M} \mathrm{Fe}^{3+}$, the amount of algae reduced to $4.7 \times 10^{6}$ and $2.6 \times 10^{6}$ cells $/ \mu$ mole $\mathrm{Fe}^{3+}$, respectively. Therefore, further development of $\mathrm{Fe}^{3+}$ flocculation was performed using $250 \mu \mathrm{M} \mathrm{Fe}^{3+}$ because at this concentration algal cells were efficiently flocculated using the minimum quantity of chemicals to produce a floc that was densely packed with cells. 
Adjustment of Thalassiosira pseudonana culture $\mathrm{pH}$ within the range 5 to 10 prior to ferric flocculation affected both flocculation efficiency and the structure of the formed floc. Flocculation efficiency at $\mathrm{pH} 5$ was significantly $(\mathrm{P}=0.05)$ lower than at higher $\mathrm{pH}$. Between $\mathrm{pH} 6$ and 9 the efficiency was high (average 81 to 89\%), but variable. At $\mathrm{pH} 10$ there was an increase in efficiency and a reduction in variability (97 $\pm 2 \%$ ) (Fig. 1). Although the variation in flocculation efficiency resulted in no significant difference in flocculation efficiency over the $\mathrm{pH}$ range 6 to 10, there was an improvement in floc structure. At pH 9 to 10, the formed flocs were larger, more robust and settled more rapidly than those produced at lower $\mathrm{pH}$ levels. Chemical analysis of flocs showed that the percentages of added iron contained within flocs ranged from 10 to $34 \%$ at $\mathrm{pH} 5,43$ to $78 \%$ between $\mathrm{pH} 6$ to 8 and from 95 to $112 \%$ between $\mathrm{pH} 9$ to 10 . The apparent net gain in total iron over the latter $\mathrm{pH}$ range presumably occurred as a result of precipitation of some of the iron that was present as a micronutrient in the growth media.

Because efficiency increased at high $\mathrm{pH}$, flocculation efficiency versus $\mathrm{Fe}^{3+}$ concentration was re-evaluated with cultures pre-adjusted to $\mathrm{pH} 9.5$ (Fig. 2). For cultures with no $\mathrm{pH}$ adjustment, $\mathrm{Fe}^{3+}$ concentrations below $250 \mu \mathrm{M}$ produced variable, inefficient flocculation. However, pre-adjusting the culture to $\mathrm{pH} 9.5$ reduced the lower $\mathrm{Fe}^{3+}$ limit that produced efficient flocculation from $250 \mu \mathrm{M}$ to $62.5 \mu \mathrm{M}$. At this level, efficiency was $70 \pm 7 \%$ compared to $29 \pm 34 \%$ for non $\mathrm{pH}$-adjusted cultures. A similar response was also found for another diatom, Attheya septentrionalis when flocculated with pre-adjustment of culture $\mathrm{pH}$ to 9.5 . At $\mathrm{Fe}^{3+}$ concentrations below $62.5 \mu \mathrm{M}$, flocculation rapidly became inefficient and more variable.

Ferric induced flocculation was also assessed for Isochrysis sp. (T.ISO). However, efficiency was poor and variable. For cultures pre-adjusted to $\mathrm{pH} 9.5$ and flocculated with $\left[\mathrm{Fe}^{3+}\right]$ from 62.5 to $500 \mu \mathrm{M}$, the efficiency of algal flocculation increased with increasing $\mathrm{Fe}^{3+}$ concentration to reach a maximum of $31 \%$ at an $\left[\mathrm{Fe}^{3+}\right]$ of $500 \mu \mathrm{M}$.

De-flocculation of ferric floc was accomplished through chelation of iron with EDTA at low $\mathrm{pH}$ (4.5). However, this procedure was not used in the preliminary feeding experiment, due to the likely negative effects on the algal cells and possible toxic effects of residual EDTA on animals. In this experiment, minimal iron concentration was used to flocculate the algae. Algal cells were partially released from the floc by shaking the daily feed ration before fully diluting it for feeding.

\section{2. $\quad p H$-induced flocculation of Thalassiosira pseudonana}

When adjusting the $\mathrm{pH}$ of cultures, during the evaluation of $\mathrm{Fe}^{3+}$ flocculation, a buffering region was encountered between $\mathrm{pH} 10.5$ to 11 . In this region, a precipitate formed that entrapped the algae. Flocculation, induced by high $\mathrm{pH}$ was then evaluated as an alternative to $\mathrm{Fe}^{3+}$ flocculation. The formation of this precipitate was independent of the presence of algal cells. Titrating seawater with $\mathrm{NaOH}$ to a concentration of $4 \mathrm{mM}$ caused the $\mathrm{pH}$ to increase rapidly to $\mathrm{pH} 10.6$. Continued addition of $\mathrm{NaOH}$ up to a concentration of $90 \mathrm{mM}$, only increased the $\mathrm{pH}$ to 11 due to the inherent buffering capacity of the seawater. A fine, white precipitate formed after addition of $4 \mathrm{mM} \mathrm{NaOH}$ and continued to form in a linear relationship in the buffering region according to the equation: 
Floc mass (mg DW $250 \mathrm{~mL}^{-1}$ seawater $)=9.74[\mathrm{NaOH} \mathrm{mM}]-8.71 \quad \mathrm{r}^{2}=0.99 ; \mathrm{P}<$ 0.05

The precipitate was close to neutral buoyancy and hence was very slow to settle. Addition of the polyelectrolyte, flocculation enhancer (LT-25) greatly increased the size of flocs and their settling rate. The bulk of the settled floc, and hence the concentration factor, reflected the quantity of $\mathrm{NaOH}$ added to form the precipitate. Experiments were undertaken to determine the minimum $\mathrm{NaOH}$ addition over the range 3 to $13 \mathrm{mM}$, with the use of polyelectrolyte that would reliably flocculate cells of Thalassiosira pseudonana (Fig. 3). Average flocculation efficiency increased according to the exponential equation:

Efficiency $(\%)=94.28-295.2 \times\left(0.6831^{[\mathrm{NaOH}]}\right) \quad \mathrm{r}^{2}=0.97$ and where $[\mathrm{NaOH}]=\mathrm{mM}$.

\subsection{Scale up and quality of stored concentrates from $\mathrm{pH}$-induced flocculation of Thalassiosira pseudonana}

Three Thalassiosira pseudonana $130 \mathrm{~L}$ cultures were flocculated after adding $\mathrm{NaOH}$ (to $8 \mathrm{mM}$ ) and polyelectrolyte. Flocs formed rapidly and efficiently (89\%), and had settled to $5 \mathrm{~L}$ by $15 \mathrm{~min}$. In one culture, the $\mathrm{pH}$ of the harvested floc was lowered with $\mathrm{HCl}$ to $\mathrm{pH} 8.7$ and floc volume reduced to $980 \mathrm{~mL}$ after $2.5 \mathrm{hr}$ and to $720 \mathrm{~mL}$ overnight $\left(4^{\circ} \mathrm{C}\right)$. Changes to the clarity and colour of the floc slurry occur during this initial $\mathrm{pH}$ adjustment. As acid is added, hydroxides precipitated during flocculation begin to re-dissolve. This causes the clarity of the floc slurry to increase and the colour to intensify as the white hydroxides dissolve. Flocs become small $(2-5 \mathrm{~mm})$, denser and will rapidly settle to a lower volume. After settling overnight, the $\mathrm{pH}$ was then reduced further using $\mathrm{HCl}$ to 7.6 and floc volume fell rapidly to $290 \mathrm{~mL}$ and then to $160 \mathrm{~mL}$ overnight $\left(4^{\circ} \mathrm{C}\right)$ - equivalent to $\approx 800$-fold concentration at $89 \%$ harvest efficiency. At this stage, flocs are densely packed aggregations of algal cells. These aggregations will readily dissociate to single cells upon dilution in seawater and gentle mixing. In another culture, $\mathrm{pH}$ was reduced in one step to 6.8 and floc volume fell to $285 \mathrm{~mL}$ overnight $\left(4^{\circ} \mathrm{C}\right)$. This continued to settle further over $2 \mathrm{~d}$ to be $175 \mathrm{~mL}$ or a 725 -fold concentration.

Chlorophyll $a$ levels in the three concentrates of Thalassiosira pseudonana were 804,788 and $724 \mu \mathrm{g} \mathrm{mL}^{-1}$. In one of the three concentrates the chlorophyll $a$ concentration increased during the first 3 weeks of storage at $4^{\circ} \mathrm{C}$ from 804 to $983 \mu \mathrm{g}$ $\mathrm{mL}^{-1}$. However, after prolonged storage ( $60 \mathrm{~d}$ ) chlorophyll $a$ decreased on average by $23 \%$ for all three concentrates. All concentrates showed a slow rate of formation of phaeopigments detected as shifts in the absorbance scans of the chlorophyll extracts (Fig. 4). For one T. pseudonana concentrate, there had been only a partial shift in the chlorophyll Soret peak from $\lambda 430 \mathrm{~nm}$ to $\lambda 410 \mathrm{~nm}$ after $60 \mathrm{~d}$ of storage at $4^{\circ} \mathrm{C}$ (Fig 4a). The other two concentrates had higher $\lambda 410 \mathrm{~nm}$ peaks but the $\lambda 430$ was still distinct. The rate of formation of phaeopigments in the $\mathrm{pH}$ flocculated concentrates was much slower than in concentrates produced by centrifugation (Alfa Laval cream separator) (Fig. 4a \& b).

Larger volume cultures of Thalassiosira pseudonana (500 L and $1000 \mathrm{~L})$ were $\mathrm{pH}$-flocculated in the same manner as described for $130 \mathrm{~L}$ cultures. Flocculation was rapid ( $\sim 10 \mathrm{~min}$ ), efficient ( 85 to $90 \%$ ) and flocs were larger than those produced in smaller volumes. The larger size (up to $2 \mathrm{~cm}$ ) of flocs is a result of lower shear forces 
that occur in large culture volumes during the coalescing of aggregates into flocs. Large, settled flocs broke up to form a slurry during collection. The $\mathrm{pH}$ of the collected slurry of floc was adjusted using concentrated $\mathrm{HCl}$ to $\mathrm{pH} 7.5$. The final concentration factors were 500 -fold and 200 -fold for the $500 \mathrm{~L}$ and $1000 \mathrm{~L}$ culture, respectively. The lower concentration factor for the $1000 \mathrm{~L}$ culture was a result of vessel design. The vessels large surface area to volume combined with the tanks flat base meant the settled floc was diluted with supernatant during recovery of the floc.

\section{4. $\quad$ pH-induced flocculation of other microalgae}

A range of other microalgae was assessed by $\mathrm{pH}$-induced flocculation. Culture volumes included $10 \mathrm{~L}$ (Tetraselmis suecica), $80 \mathrm{~L}$ (Chaetoceros calcitrans, $C$. muelleri, Skeletonema sp., Rhodomonas salina), 130 L (Attheya septentrionalis), $500 \mathrm{~L}$ (Nitzschia closterium) and $1000 \mathrm{~L}$ (C. muelleri). All these species were successfully flocculated with similar efficiencies $(\geq 85 \%)$ and settling rates as observed for Thalassiosira pseudonana. The passive nature of the flocculation and deflocculation processes was evident by the high level (40-70\%) of motility in cell concentrates of $T$. suecica and $R$. salina. Interestingly, some microalgae were poorly entrapped in the flocculation process resulting in low harvest recoveries. This is likely a result of a failure of the initial coagulation process due to incompatible cell surface chemistry. The common aquaculture species, Nannochloropsis oculata and Isochrysis sp. (T.ISO) were two algae that were poorly $(<30 \%)$ flocculated.

Some differences were observed following deflocculation. For the two Chaetoceros species, adjustment of $\mathrm{pH}$ to 7.5 resulted in complete deflocculation. However, algae were very slow to settle during storage at $4{ }^{\circ} \mathrm{C}$, taking 5-6 d for the majority of cells to sink. This slow secondary settling was probably due to their setae. This problem was overcome by adjusting the $\mathrm{pH}$ of the floc to 8-8.5, which left the cells slightly clumped with subsequent rapid settling $(24 \mathrm{~h})$. Cells were easily resuspended to single cells by gently hand-mixing.

Microscopic examination indicated that cells of all species successfully flocculated except Rhodomonas salina were in good physical condition after 4 weeks of storage at $4^{\circ} \mathrm{C}$. Under microscopic examination the cells were non differentiable from those of the original culture, cells structures remained intact and there was no obvious loss or collapsing of the cytoplasm. However, concentrates of $R$. salina were only stable for $\sim 1$ week after which phycoerythrin was released with subsequent cell lysis.

\subsection{Thalassiosira pseudonana concentrates as bivalve feeds - preliminary experiment}

The live Thalassiosira pseudonana diet and algal concentrate (excluding ferricflocculated) diets were fed at a similar daily DW and AFDW of $10.2 \pm 0.2 \mathrm{mg}$ and $8.3 \pm 0.6 \mathrm{mg}$ per culture unit respectively. The ferric-flocculated diet contained $84 \%$ of the $\mathrm{Fe}^{3+}$ (as hydroxides) used to induce flocculation, equivalent to $22 \mathrm{mM} \mathrm{Fe}^{3+}$ in the diet. This insoluble matter contributed to the high ash content ( $30 \% \mathrm{DW})$ of this diet (Table 2) and it was fed at a daily rate equivalent to $10 \mathrm{mg}$ ferric-free DW, calculated from the initial culture DW and accounting for the flocculation efficiency and harvest concentration factor. Samples taken from the oyster chambers prior to the daily addition 
of algae were effectively free of residual algal cells with numbers well below an accurate measurement or estimation using a haemocytometer.

The protein $\% \mathrm{DW}$ of the diets ranged from $32.1 \%$ for the ferric-flocculated diet to $45.7 \%$ for the laboratory-centrifuged diet (Table 2), while lipid ranged from $26.8 \%$ for the ferric-flocculated diet to $45.6 \%$ for the live algal diet. Dietary carbohydrate was the most variable component (from 5.4 to $14 \%$ of DW), due in part to the low percentage (DW) of mono-oligosaccharides in the cream separator prepared diet $(0.8 \%)$ compared to the remaining diets (average $=3.44 \%$ ).

When fed to the oysters, the live algal diet produced the fastest growth rate $\left(293 \%\right.$ increase in oyster DW; $\left.\mathrm{k}=0.062 \mathrm{~d}^{-1}\right)$, followed by the $\mathrm{pH}$-flocced and laboratory centrifuged diets $\left(202 \%\right.$ increase; $\mathrm{k}=0.050 \mathrm{~d}^{-1}$ and $183 \%$ increase; $\mathrm{k}=$ $0.047 \mathrm{~d}^{-1}$, respectively) then the ferric-flocced and cream separator diets (93\% increase; $\mathrm{k}=0.030 \mathrm{~d}^{-1}$ and $86 \%$ increase; $\mathrm{k}=0.028 \mathrm{~d}^{-1}$, respectively) (Table 2 and Fig. 5). Unfed oysters did not increase in DW. Similar trends were observed when growth was measured on a basis of changes in AFDW, except that the $\mathrm{pH}$-flocced diet outperformed the laboratory centrifuge diet, and unfed oysters had negative growth rates (Table 2 and Fig. 5).

\section{6. $\quad$ Assessment of algal concentrates as bivalve feeds-commercial rearing}

The two experiments assessing concentrates of Chaetoceros for oysters and scallops were conducted under different conditions due to the husbandry requirements of the animals, and also the variable properties of ambient seawater passing through the upwellers. Natural levels of food particles in the inflowing seawater, as reflected by particulate organic matter (POM) and chlorophyll $a$ (an indicator of microalgae biomass) were significantly higher during Experiment 1 (POM, $0.89 \pm 0.38 \mathrm{mg} \mathrm{L}^{-1}$; chlorophyll $a, 1.19 \pm 0.39 \mu \mathrm{g} \mathrm{L}^{-1}$ ) than Experiment $2\left(\mathrm{POM}, 0.34 \pm 0.19 \mathrm{mg} \mathrm{L}^{-1}\right.$; chlorophyll $a$, $0.67 \pm 0.13 \mu \mathrm{g} \mathrm{L}^{-1}$ ). Based on chlorophyll $a$ measurements of ambient seawater and an assumption that chlorophyll $a \approx 1.0 \%$ of microalgae DW (Brown, 1991), supplementation was estimated to increase available microalgae by $150 \%$ and $200 \%$ in Experiments 1 and 2 respectively.

In Experiment 1, the DW of non-supplemented (control) oysters increased by $401 \%$ over 25 d (Fig. 6a). Supplementation improved growth significantly with all diets. Live microalgae produced an approximate doubling of growth $(724 \%$ and $695 \%$ for Chaetoceros muelleri and C. calcitrans, respectively). Supplementation with concentrated C. muelleri produced a growth response intermediate between the control and the live $C$. muelleri treatment. No significant mortality was evident in any of the treatments; survival was estimated to be $\geq 95 \%$.

In Experiment 2, DW of non-supplemented (control) scallops over $14 \mathrm{~d}$ increased by $206 \%$ (Fig. 6b). Supplementation with the live Chaetoceros muelleri and C. calcitrans, and concentrated C. muelleri diets all produced a significant increase in growth compared to the control diet. Nevertheless, the trends for the growth response of treatments were similar to those observed for Experiment 1; i.e. C. muelleri live $\geq C$. calcitrans live $>C$. muelleri concentrate $>$ control. Survival was not significantly different between any of the treatments $(\mathrm{P}>0.05$; average $76 \pm 5 \%)$.

Selected biochemical analyses of samples pooled across both experiments showed some differences in live and concentrated Chaetoceros muelleri. The live algae contained more $\%$ DW of protein $(43 \pm 6.8$, c.f. $34.3 \pm 8.2)$ and carbohydrate $(9.8 \pm 3.6$, 
c.f. $3.9 \pm 1.8$ ) (lipid not analysed). Relative changes were most dramatic in ascorbic acid (AsA). Live C. muelleri contained $1.88 \pm 0.70 \mathrm{mg} \mathrm{g}^{-1}$, where concentrates averaged $1.14 \pm 0.73 \mathrm{mg} \mathrm{g}^{-1}$. However, concentrates that were $\leq 7$ days old (average $4 \pm$ $3 \mathrm{~d})$ contained similar concentrations of AsA $\left(1.50 \pm 0.48 \mathrm{mg} \mathrm{g}^{-1}\right)$ as live algae; whereas concentrates that were $>7$ days old (average $13 \pm 5 \mathrm{~d}$ ) contained significantly less $(0.21$ $\pm 0.17 \mathrm{mg} \mathrm{g}^{-1}$ ) than both younger concentrates and live algae.

\section{Discussion}

Flocculation was applied to concentrate a range of microalgae used as aquaculture feeds, and its efficiency $(\geq 80 \%)$ compared well to reported efficiencies of over $90 \%$ for ferric chloride flocculation of marine algae (Sukenik et al., 1988), and $\geq$ $75 \%$ for chitosan flocculation (Lubián, 1989). Moreover, the $\mathrm{pH}$-induced flocculation cell aggregates were deflocculated successfully to single cell suspension necessary for their testing as feed for bivalve molluscs.

Freshwater microalgae can be flocculated using polymers (chitosan or polyelectrolyte compounds derived from polyacrylamide) as the sole agent, but salinity levels above $5 \mathrm{~g} \mathrm{~L}^{-1}$ inhibit flocculation. Therefore, in marine systems polymer flocculants are often used in conjunction with inorganic coagulants $\left(\mathrm{Fe}^{3+}\right.$, alum, lime $)$ where they improve flocculation efficiency. Flocculation of marine microalgae using the coagulant $\mathrm{FeCl}_{3} \cdot 6 \mathrm{H}_{2} \mathrm{O}$, requires concentrations 5 to 10 times greater than those required for freshwater microalgae (Sukenik et al., 1988) due to the high ionic strength of the media reducing flocculant chemical activity and masking its active sites. In our study we first assessed a combination of $\mathrm{FeCl}_{3} \cdot 6 \mathrm{H}_{2} \mathrm{O}$ and the polymer LT-25 (a nonionic polyacrylamide derivative). Flocculation of Thalassiosira pseudonana was most rapid and efficient $(>90 \%)$ at $\mathrm{Fe}^{3+}$ concentrations above $500 \mu \mathrm{M}$, where large flocs were produced that resisted disruption and settled rapidly. However, the density of algae was $\approx$ ten-fold lower than flocs produced at $\mathrm{Fe}^{3+}$ concentrations below $250 \mu \mathrm{M}$. Pre-adjustment of culture $\mathrm{pH}$ improved flocculation efficiency with an initial optimal $\mathrm{pH}$ of 6; Alaerts and Van-Haute (1981) also reported $\mathrm{pH} 6$ to be optimal for flocculation with ferric chloride or alum. However, flocculation efficiency increased at $\mathrm{pH}$ levels above 9 where the $\mathrm{Fe}^{3+}$ concentration could be reduced to $125 \mu \mathrm{M}$ with $80 \%$ flocculation of algal cells.

Flocculation efficiency increased with increasing $\mathrm{Fe}^{+3}$ concentrations but was often variable. This variability is likely a result of micro differences in mixing rates, addition rates and culture chemistry between replicates. The $\mathrm{Fe}^{+3}$ induced flocculation process requires attachment of $\mathrm{Fe}^{+3}$ to the algal cell surface causing coagulation of cells. Concurrently, $\mathrm{Fe}^{+3}$ precipitates as hydroxides and these coalesce with the coagulated cell aggregates to form larger flocs. These competing processes lead to variability in flocculation efficiency between replicates, particularly at low flocculant concentrations. Although variability decreased at higher flocculant concentrations, the sensitivity of this method at the desired low flocculant concentrations was a driving force for the development of an alternative flocculation process.

An alternate and novel process for algal flocculation was developed using $\mathrm{pH}$ adjustment. This was based on the observation that increasing the $\mathrm{pH}$ of seawater above 10 resulted in a precipitate (likely to be $\mathrm{Ca}$ and $\mathrm{Mg}$ hydroxides) that continued to develop with increasing addition of $\mathrm{OH}^{-}$. Millamena et al. (1990) also observed 
precipitation when culture $\mathrm{pH}$ was raised to $\mathrm{pH} 10$. In our study, $\mathrm{NaOH}$ was used to increase $\mathrm{pH}$, but a similar result can be obtained using lime (Sripayatt, 1982; Millamena et al., 1990). Subsequent addition of LT-25 caused flocculation of the precipitate. When performed on algal cultures, cells were trapped in the floc that settled, concentrating the algae. Minimal bulk of floc with maximum concentration of cells was produced close to the point of formation of visible precipitate (after the addition of 6 to $10 \mathrm{mM} \mathrm{NaOH}$ ). Additional $\mathrm{NaOH}$ did not improve efficiency of algal flocculation, but increased the bulk of precipitate and formed loose flocs that did not pack so tightly when settled.

Flocs produced by addition of $\mathrm{NaOH}$ were re-adjusted to $\mathrm{pH} 7.5$ and 8 using $\mathrm{HCl}$, whereupon the bulk of the floc dissolved leaving small dense flocs consisting almost entirely of algal cells. At this stage, concentration factors were typically 25 -fold. However, upon storage at $4^{\circ} \mathrm{C}$ over $24-48 \mathrm{~h}$ the small flocs settled and the concentration factor increased from an initial $\approx 25$-fold to 700 to 800 -fold. One potential practical limitation of the flocculation process is the relatively large volume remaining after the initial flocculation process (e.g. $40 \mathrm{~L}$ after concentration of a $1000 \mathrm{~L}$ culture). Thus for the potential application of this process by aquaculture hatcheries, the need for $4^{\circ} \mathrm{C}$ storage prior to the secondary concentration could require additional domestic refrigerators or a cold-storage room dedicated for this purpose.

Despite this issue, higher residual volumes (and hence lower cell densities) may improve the shelf-life of harvested concentrates. Tredici et al. (1996) found that cell concentration $\left(\mathrm{g} \mathrm{L}^{-1}\right)$ was a highly significant factor in determining the viability (motility and photosynthetic activity) of algal cells stored $\left(4^{\circ} \mathrm{C}\right)$ as concentrates. For centrifuged concentrates of Tetraselmis suecica at $4 \mathrm{~g} \mathrm{~L}^{-1}$, they found no reduction in viability during $50 \mathrm{~d}$ at $4^{\circ} \mathrm{C}$. At cell concentrations of 20 and $60 \mathrm{~g} \mathrm{~L}^{-1}$, a high level of viability $(>70 \%)$ was maintained until around $10 \mathrm{~d}$, but then it rapidly declined to total mortality by 21-24 d. For algal pastes, cell viability was nil after two weeks. In our studies, flocculated and laboratory centrifuged cell concentrates at 6-7 g L ${ }^{-1} \mathrm{DW}$, were likely to be within a concentration range appropriate for maintaining a quality product. This may partly explain their higher nutritional value to juvenile Pacific oysters in our preliminary experiment, compared to pastes prepared using the cream separator (DW of $128 \mathrm{~g} \mathrm{~L}^{-1}$ ). However, the inferior performance of the latter may also have been due to cellular damage during harvesting and subsequent leakage of cell metabolites.

The polymer LT-25 was routinely used at $0.5 \mathrm{mg} \mathrm{L}^{-1}$, but for some microalgae this level could be reduced 5 to 10 -fold without a loss of flocculation efficiency (Knuckey, 1998). However, reducing the dose rate of the polymer had two effects; 1) flocs were less dense and settled more slowly, 2) the final settled volume of the floc was larger. There is little data published on the ecological or toxicological effect of synthetic polymer flocculants. Beim and Beim (1994) found polymer flocculants negatively affected all water ecosystems and the most acute effects were from exposure to cationic polymer flocculants. They recommended that maximum permissible concentrations be set for flocculant residues. However, the non-ionic polymer LT-25 is manufactured for the clarification of drinking water with residual non-polymerised acrylamide below permissible levels. It is classified non-hazardous according to Worksafe Australia criteria [NOHSC:1008(1994)]. Its final concentration within the juvenile bivalve culture systems was not assessed, but assuming all added polymer was retained in the concentrates, then following dilution maximum concentrations would be 
$1 \mathrm{pg} \mathrm{mL} \mathrm{L}^{-1}$. Across all the experiments, there was no increase in mortality in any of the concentrate treatments utilising LT-25.

Cells harvested by $\mathrm{pH}$-induced flocculation, although densely packed in flocs, were indistinguishable from non-flocculated cells when viewed by light microscopy. This contrasted to centrifuged algal cells that were clearly damaged, except for some small, tough green algal species, e.g. Stichococcus sp. (Knuckey, 1998). Deflocculation produced dense, single cell suspensions of cells that appeared unaffected. For motile species such as Tetraselmis suecica and Rhodomonas salina, between $40-70 \%$ of cells were still motile, indicating very little cell disruption. This demonstrated the low-shear nature of flocculation compared to continuous-flow centrifugation where concentration of another cryptophyte Geminigera cryophila produced an algal paste consisting entirely of cell fragments (Knuckey, 1998).

Chlorophyll $a$ measurements also indicated that cells from $\mathrm{pH}$-induced flocculated concentrates were in better physical condition than those produced by centrifugation. Spectrophotometric scans of chlorophyll extracts of 21 day old concentrates of $T$. pseudonana showed no sign of degradation of chlorophyll and formation of phaeopigments, whereas extracts from 24 day old centrifuged pastes of the same alga showed only peaks characteristic of phaeopigments (Knuckey, 1998). Scans of 60 day old concentrates showed a mixture of chlorophyll $a$ and phaeopigments similar to a 7 day old centrifuged paste (Fig 4). For centrifuged pastes, degradation of chlorophyll coincides with a progressive loss of ascorbic acid and leaching of the remaining ascorbic acid upon paste re-suspension, indicating a general loss of cell membrane integrity (Knuckey, 1998). Although not a measure of cell viability, the stability of chlorophyll in concentrates produced by $\mathrm{pH}$-induced flocculation is evidence for maintained cell integrity and the conservation of cell metabolites. It is likely that further improvements to concentrate quality and shelf-life could be made through refinement of storage conditions and the addition of preservatives and common food additives. However, Heasman et al., (2000) found the benefits of such treatments to be unpredictable and highly species specific.

The preliminary feeding experiment compared the nutritional value of concentrates, prepared using four different processes, as complete feeds for juvenile oysters. The $\mathrm{pH}$-flocculated diet was the best of the concentrate diets giving a growth response (based on \% increase in DW and AFDW) about two-thirds of that using the live algae. This response was slightly better than that given by concentrates prepared using a laboratory centrifuge, but markedly better than concentrates prepared by the cream separator and ferric chloride flocculation.

Based on the findings of this experiment, the two follow up experiments assessed $\mathrm{pH}$-flocculates as partial diets (i.e. as supplement to natural particles in seawater) for juvenile oysters and scallops under similar conditions to those of commercial rearing. Moreover, concentrates of Chaetoceros muelleri were prepared from mass-cultures of algae grown by industry. In both experiments, supplementation with concentrates significantly improved the growth of the bivalves compared to controls, by $50 \%$ for oysters and $44 \%$ for scallops, albeit not to the same extent as live C. muelleri (80\%), nor apparently another live alga, C. calcitrans (74\% for oysters, $60 \%$ for scallops). Nevertheless, these experiments demonstrated a proof-of-concept for a commercial application of concentrates, especially for use at a remote nursery site without on-site mass-algal culture facilities. We also established that another Chaetoceros strain, i.e. C. calcitrans forma pumilum was efficiently flocculated using 
the $\mathrm{pH}$-induced process described here, and moreover its concentrates gave equivalent growth as the same live alga when fed as an $80 \%$ diet component to larval and juvenile C. gigas within experimental-scale systems (Brown and Robert, 2002). In a follow-up study, flocculation was also successful in harvesting Pavlova lutheri (efficiency $=$ $100 \%$ ), though cells showed a rapid deterioration during their second week of storage (Ponis et al., 2003). Concentrates produced using the $\mathrm{pH}$-induced process have also been assessed as algal feeds for larvae of the tiger prawn Penaeus monodon (D'Souza et al., 2002). In this study, six week old concentrates of C. muelleri or T. pseudonana promoted similar survival rates to that of fresh C. muelleri although development rates were slower.

In summary, a novel process for flocculation of microalgae was developed based on $\mathrm{pH}$ adjustment. It is rapid, inexpensive and relatively simple, and was efficient for harvesting diatoms, prasinophytes and cryptophytes. The process appeared to be less damaging to cells than centrifugation (especially using a cream separator) based on chlorophyll analysis and microscopic examination. Cells were readily resuspended in seawater and they had a good nutritional value for juvenile oysters and scallops as major diet components. Flocculation is presented as a cost-effective alternative for preparing microalgal concentrates for the aquaculture industry and is suited for on-site production by hatcheries.

\section{Acknowledgements}

The initial phase of this study was partly funded by the Cooperative Research Centre for Aquaculture, Australia. Dr Robert's contribution to the project was funded by French FAIR (MOCEDIM Project). We acknowledge the assistance of Shellfish Culture Ltd, Tasmania, Australia, who provided infrastructure and technical expertise to assist in the feeding experiments with bivalves. We also thank Dr Frank Coman and Dr Mike Rimmer who reviewed an earlier version of this manuscript. 


\section{References}

Alaerts, G., Van-Haute, A., 1981. Flocculation of brackish water from a tidal river. Water Res. 15, 517-523.

Beim, A.A., Beim, A.M., 1994. Comparative ecological-toxicological data on determination of maximum permissible concentrations (MPC) for several flocculants. Environ. Technol. 15, 195-198.

Brown, M.R., 1991. The amino acid and sugar composition of 16 species of microalgae used in mariculture. J. Exp. Mar. Biol. Ecol. 145, 79-99.

Brown M.R., Miller, K.A., 1992. The ascorbic acid content of eleven species of microalgae used in mariculture. J. Appl. Phycol. 4, 205-215.

Brown, M., Robert, R., 2002. Preparation and assessment of microalgal concentrates as feeds for larval and juvenile Pacific oyster (Crassostrea gigas). Aquaculture 207, 289-309.

Brown, M.R., McCausland, M.A., Kowalski, K., 1998. The nutritional value of four Australian microalgae fed to Pacific oyster Crassostrea gigas spat. Aquaculture, $165,281-293$.

Clayton, J.R. jr., Dortch, Q., Thoreson, S.S., Ahmed, S.I., 1988. Evaluation of methods for the separation and analysis of proteins and free amino acids in phytoplankton samples. J. Plankton Res., 10: 341-358.

Coutteau, P., Sorgeloos, P., 1992. The use of algal substitutes and the requirement for live algae in the hatchery and nursery rearing of bivalve molluscs: an international survey. J. Shellfish Res. 11, 467-476.

Csordas, A., Wang, J.-K., 2004. An integrated photobioreactor and foam fractionation unit for the growth and harvest of Chaetoceros spp. in open systems. Aquacult. Eng. 30, 15-30.

D’Souza, F.M.L., Knuckey, R.M., Hohmann, S., Pendrey, R.C., 2002. Flocculated microalgae concentrates as diets for larvae of the tiger prawn Penaeus monodon Fabricius. Aquaculture Nutrition, 8: 113-120.

Dubois, M., Gillies, K.A., Hamilton, J.K., Rebers, P.A. and Smith, F., 1956. Colorimetric method for the determination of sugars and related substances. Anal. Chem. 28, 350-356.

Guillard, R.R.L., Ryther, J.H., 1962. Studies on marine planktonic diatoms. I. Cyclotella nana Hustedt, and Detonula confervacea (Cleve) Gran. Can. J. Microbiol. 8, 229-239.

Heasman, M., Diemar, J., O’Connor, W., Sushames, T., Foulkes, L., 2000. Development of extended shelf-life micro-algae concentrate diets harvested by centrifugation for bivalve molluscs - a summary. Aquacult. Res. 31, 637-659.

Jeffrey, S.W., Humphrey, G.F., 1975. New spectophotometric equations for determining chlorophylls $a, b_{1}, c_{1}$ and $c_{2}$ in higher plants, algae and natural phytoplankton. Biochem. Physiol. Pflanz. 167, 191-194.

Knauer, J., Southgate, P.C., 1999. A review of the nutritional requirements of bivalves and the development of alternative and artificial diets for bivalve aquaculture. Rev. Fish. Sci. 7, 241-280.

Knuckey, R.M., 1998. Australian microalgae and microalgal concentrates for use as aquaculture feeds. Ph.D. thesis, University of Tasmania, $254 \mathrm{pp}$.

Kochert, G., 1978. Quantitation of the macromolecular components of microalgae. In: 
J. A. Hellebust, J. S. Craigie (Eds.), Handbook of Phycological Methods:

Physiological and Biochemical Methods. Cambridge University Press, Cambridge, pp. 189-195.

Langdon, C., Önal, E., 1999. Replacement of living microalgae with spray-dried diets for the marine mussel Mytilus galloprovincialis. Aquaculture 180, 283-294.

Lowry, O.H., Rosebrough, N.J., Farr, A.L., Randall, R.J., 1951. Protein measurement with the Folin phenol reagent. J. Biol. Chem. 193, 265-275.

Lubián, L. M., 1989. Concentrating cultured marine algae with chitosan. Aquacult. Eng. $8,257-265$.

McCausland, M.A., Brown, M.R., Barrett, S.M., Diemar, J.A., Heasman, M.P., 1999. Evaluation of live and pasted microalgae as supplementary food for juvenile Pacific oysters (Crassostrea gigas). Aquacult. Res. 174, 323-342.

Millamena, O.M., Aujero, E. J., Borlongan, I. G., 1990. Techniques on algae harvesting and preservation for use in culture as larval food. Aquacult. Eng. 9, 295-304.

Nell, J.A., O'Connor, W.A., 1991. The evaluation of fresh algae and stored algal concentrates as a food source for Sydney rock oyster, Saccostrea commercialis (Iredale and Roughley), larvae. Aquaculture 99, 277-284.

Poelman, E., De Pauw, N., Jeurissen, B., 1997. Potential of electrolytic flocculation for recovery of micro-algae. Resources, Conservation and Recycling 19, 1-10.

Ponis, E., Robert, R., Parisi, G., 2003. Nutritional value of fresh and concentrated algal diets for larval and juvenile Pacific oysters (Crassostrea gigas). Aquaculture 221, 491-505.

Robert R., Trintignac P., 1997. Substitutes for live microalgae in mariculture: a review. Aquat. Living Resources 10, 315-327.

Rossingol, N., Vandanjon, L., Jaouen, P., Quéméneur, F., 1999. Membrane technology for the continuous separation microalgae/culture medium: compared performances of cross-flow microfiltration and ultrafiltration. Aquacult. Eng. 20, 191-208.

Sandbank, E., 1978. The utilization of microalgae as feed for fish. Ergeb. Limnol. 11, 108-120.

Sripayatt, P., 1982. Phytoplankton flocculation. Thai-Fish. Gaz., 35, 609-611.

Sukenik, A., Bilanovic, D., Shelef, G., 1988. Flocculation of microalgae in brackish and sea waters. Biomass 15, 187-199.

Tredici, M., Montaini, E. Chini Zitelli, G., Carobbi, S., 1996. Centro di Studio die Microorganismi Autrotrofi (Florence). In: European Commission Final Report AIR1-CT92-(0286)MANTA - Microalgae Biomass from Photobioreactors as Food for Fish and Shellfish Larvae (MANTA). European Commission, 138 pp.

Vogel, A.I., (1978). Colorimetry and spectrophotometry. In Vogel's Textbook of Quantitative Inorganic Analysis Including Elemental Instrumental Analysis $4^{\text {th }}$ edition. Eds. J. Bassett, R.C. Denney, G.H. Jeffrey and J. Mendham, Longman, New York, pp 742-743.

Whyte, J.N.C., 1987. Biochemical composition and energy content of six species of phytoplankton used in mariculture of bivalves. Aquaculture 60, 231-241. 
Table 1 Microalgae species assessed for their ability to be concentrated by flocculation.

\begin{tabular}{|c|c|c|c|c|c|}
\hline \multirow{2}{*}{$\begin{array}{l}\text { Algal class } \\
\text { Cryptophyceae }\end{array}$} & \multicolumn{2}{|c|}{ Species and CSIRO culture code } & \multirow{2}{*}{$\begin{array}{l}\text { Cell density } \\
\left(\text { cells } \mathrm{mL}^{-1}\right) \\
1-2 \times 10^{6}\end{array}$} & \multirow{2}{*}{$\begin{array}{c}\text { Flocculation method } \\
\mathrm{pH}\end{array}$} & \multirow{2}{*}{$\begin{array}{l}\text { Flocculation efficiency } \\
(\%) \\
85-90\end{array}$} \\
\hline & Rhodomonas salina & CS-24 & & & \\
\hline \multirow[t]{6}{*}{ Bacillariophyceae } & Attheya septentrionalis & $\mathrm{CS}-425$ & $1-1.5 \times 10^{6}$ & Ferric and $\mathrm{pH}$ & $85-95$ \\
\hline & Chaetoceros calcitrans & $\mathrm{CS}-178$ & $1-2 \times 10^{7}$ & $\mathrm{pH}$ & $95-99$ \\
\hline & Chaetoceros muelleri & CS-176 & $2-3 \times 10^{6}$ & $\mathrm{pH}$ & $95-97$ \\
\hline & Nitzschia closterium & CS-5 & $1-2 \times 10^{6}$ & $\mathrm{pH}$ & $90-95$ \\
\hline & Thalassiosira pseudonana & CS-173 & $2-4 \times 10^{6}$ & Ferric and $\mathrm{pH}$ & $80-95$ \\
\hline & Skeletonema sp. & $\mathrm{CS}-252$ & $3-6 \times 10^{6}$ & $\mathrm{pH}$ & $95-98$ \\
\hline Eustigmatophyceae & Nannochloropsis oculata & CS-179 & $1-2 \times 10^{7}$ & $\mathrm{pH}$ & $<30$ \\
\hline Prasinophyceae & Tetraselmis suecica & CS-187 & $4-8 \times 10^{5}$ & $\mathrm{pH}$ & $85-95$ \\
\hline Prymnesiophyceae & Isochrysis sp. (T.ISO) & CS-177 & $3-4 \times 10^{6}$ & Ferric and $\mathrm{pH}$ & $<30$ \\
\hline
\end{tabular}


Table 2 Gross composition (GC; \% of DW) of $T$. pseudonana diets $(\mathrm{n}=3)$, and the corresponding growth responses of $C$. gigas oyster spat $(n=4)$. For growth responses, values across the same row sharing a common superscript letter are not significantly different $(P>0.05)$.

\begin{tabular}{|c|c|c|c|c|c|c|}
\hline & \multirow[b]{2}{*}{ Unfed control } & \multirow[b]{2}{*}{ Live algae } & \multicolumn{4}{|c|}{ Concentration method } \\
\hline & & & pH-flocced & Ferric-flocced & $\begin{array}{l}\text { Laboratory } \\
\text { centrifuge }\end{array}$ & Cream separator \\
\hline Protein & $\mathrm{n} / \mathrm{a}$ & $37.9 \pm 6.97$ & $43.6 \pm 2.19$ & $32.1 \pm 2.47$ & $45.7 \pm 0.22$ & $37.8 \pm 1.82$ \\
\hline Lipid & $\mathrm{n} / \mathrm{a}$ & $45.6 \pm 8.37$ & $34.8 \pm 0.80$ & $26.8 \pm 3.34$ & $38.2 \pm 0.61$ & $38.8 \pm 7.25$ \\
\hline $\mathrm{CHO}$ (mono/oligo + polysaccharides) & $\mathrm{n} / \mathrm{a}$ & $5.74+8.43$ & $3.77+6.91$ & $1.19+5.06$ & $3.14+5.04$ & $0.91+4.55$ \\
\hline Carbohydrate (Total) & $\mathrm{n} / \mathrm{a}$ & $14.2 \pm 2.89$ & $10.7 \pm 3.61$ & $6.3 \pm 1.03$ & $8.2 \pm 3.38$ & $5.4 \pm 0.58$ \\
\hline Ash & $\mathrm{n} / \mathrm{a}$ & $11.6 \pm 2.86$ & $17.7 \pm 1.15$ & $29.8 \pm 3.22$ & $16.9 \pm 1.18$ & $19.4 \pm 5.06$ \\
\hline Total dietary energy $(\mathrm{KJ})^{*}$ & & 6.43 & 5.50 & 6.14 & 5.59 & 5.45 \\
\hline \multicolumn{7}{|l|}{ Oyster growth responses } \\
\hline$\%$ increase in DW & $5 \pm 11^{\mathrm{d}}$ & $293 \pm 15^{\mathrm{a}}$ & $202 \pm 13^{b}$ & $93 \pm 14^{\mathrm{c}}$ & $183 \pm 10^{b}$ & $86 \pm 4^{\mathrm{c}}$ \\
\hline$\%$ increase in AFDW & $-16 \pm 6^{e}$ & $292 \pm 11^{\mathrm{a}}$ & $184 \pm 9^{b}$ & $104 \pm 10^{d}$ & $167 \pm 5^{c}$ & $93 \pm 3^{d}$ \\
\hline Apparent average growth efficiency & & 42 & 30 & 13 & 28 & 16 \\
\hline
\end{tabular}

* based on sum of total DW fed to oysters over the experiment, and the constituent \% of protein, carbohydrate and lipid and their energetic values 20.1, 17.6 and $39.7 \mathrm{KJ} \mathrm{g}^{-1}$, respectively (Whyte, 1987). 
Fig. 1. Flocculation efficiency of Thalassiosira pseudonana $(250 \mathrm{~mL})$ with preadjusted $\mathrm{pH}$, ferric chloride dosed at $250 \mu \mathrm{M}$ and polyelectrolyte LT-25 (0.05\%) added at $1 \mathrm{~mL} \mathrm{~L}^{-1}$. Error bars are \pm 1 s.d. $(\mathrm{n}=3)$.

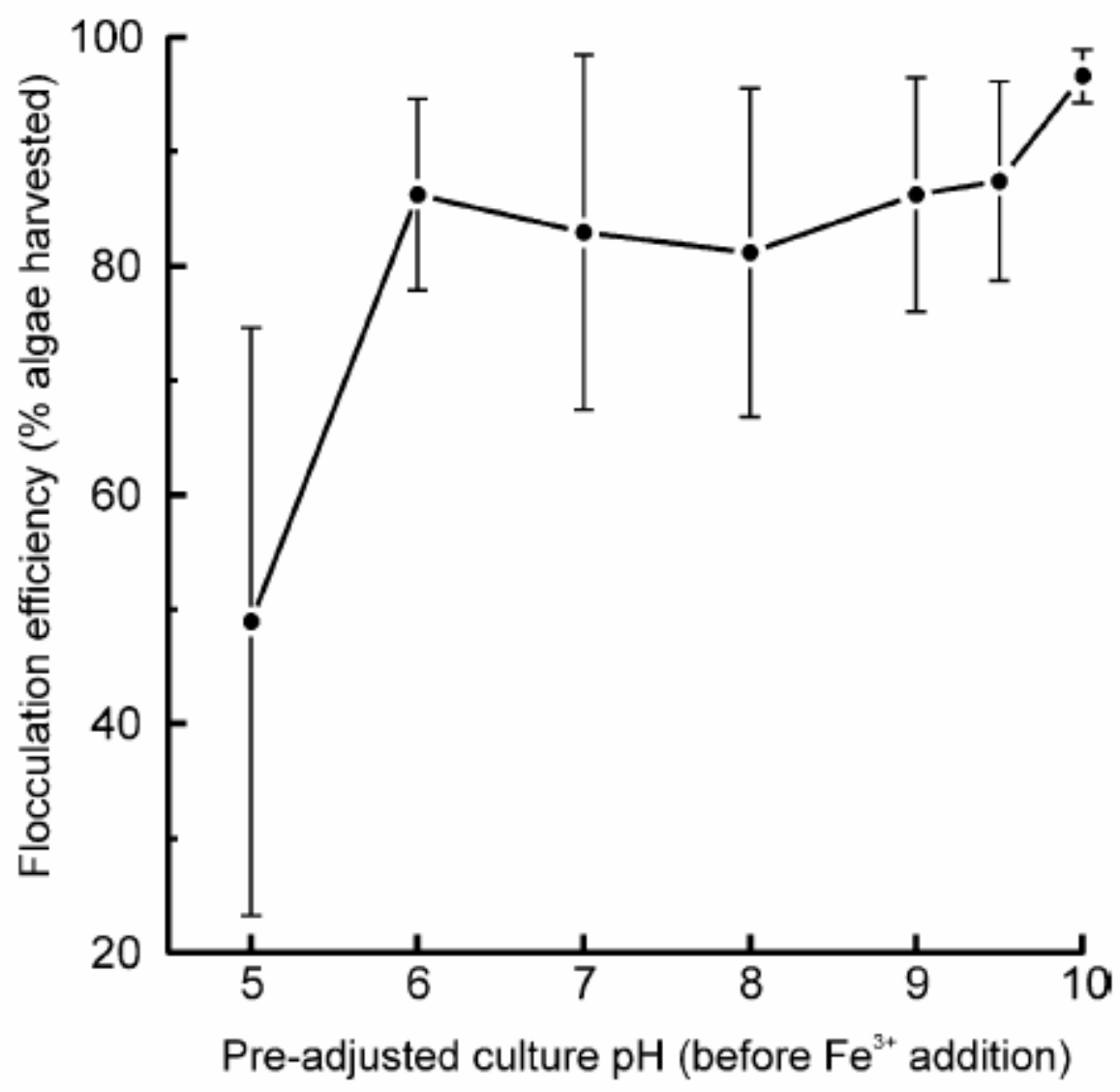


Fig. 2. Flocculation efficiency of Thalassiosira pseudonana $(250 \mathrm{~mL})$, pre-adjusted to $\mathrm{pH} 9.5$, over a ferric chloride concentration from 20 to $250 \mu \mathrm{M}$ and with polyelectrolyte LT-25 (0.05\%) added at $1 \mathrm{~mL} \mathrm{~L}^{-1}$. Efficiency compared to flocculation of cultures with unadjusted $\mathrm{pH}$. Error bars are \pm 1 s.d. $(\mathrm{n}=3)$.

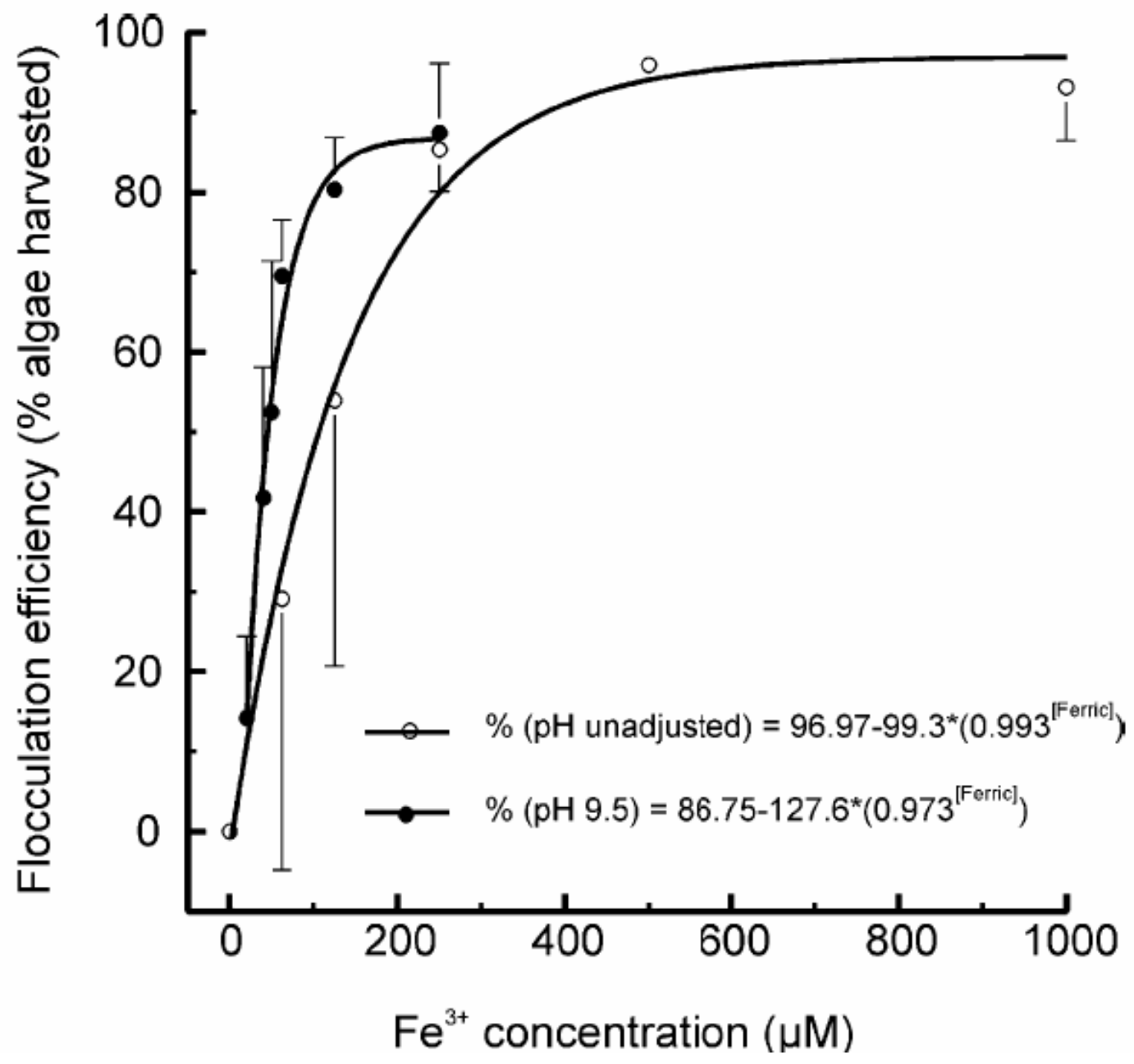


Fig. 3. Flocculation efficiency of Thalassiosira pseudonana $(250 \mathrm{~mL})$ induced by increasing concentration of $\mathrm{NaOH}$ with polyelectrolyte LT-25 $(0.05 \%)$ added at $1 \mathrm{~mL}$ $\mathrm{L}^{-1}$. Error bars are \pm 1 s.d. $(\mathrm{n}=4)$.

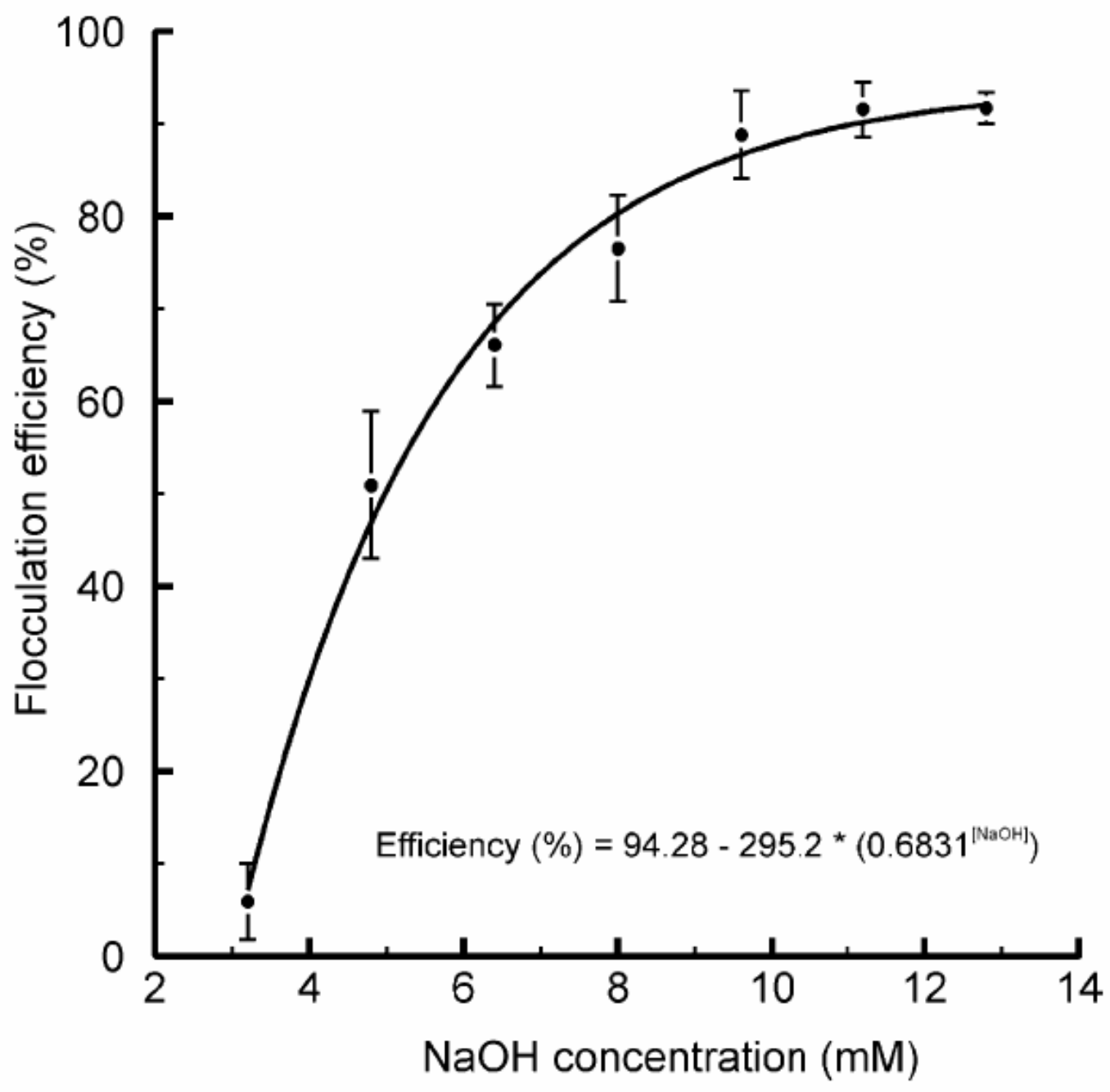


Fig. 4. Detection over time of phaeopigment (chlorophyll degradation) peaks in chlorophyll extracts of concentrates of Thalassiosira pseudonana produced by centrifugation (Fig. 4a) or pH induced flocculation (Fig. 4b).
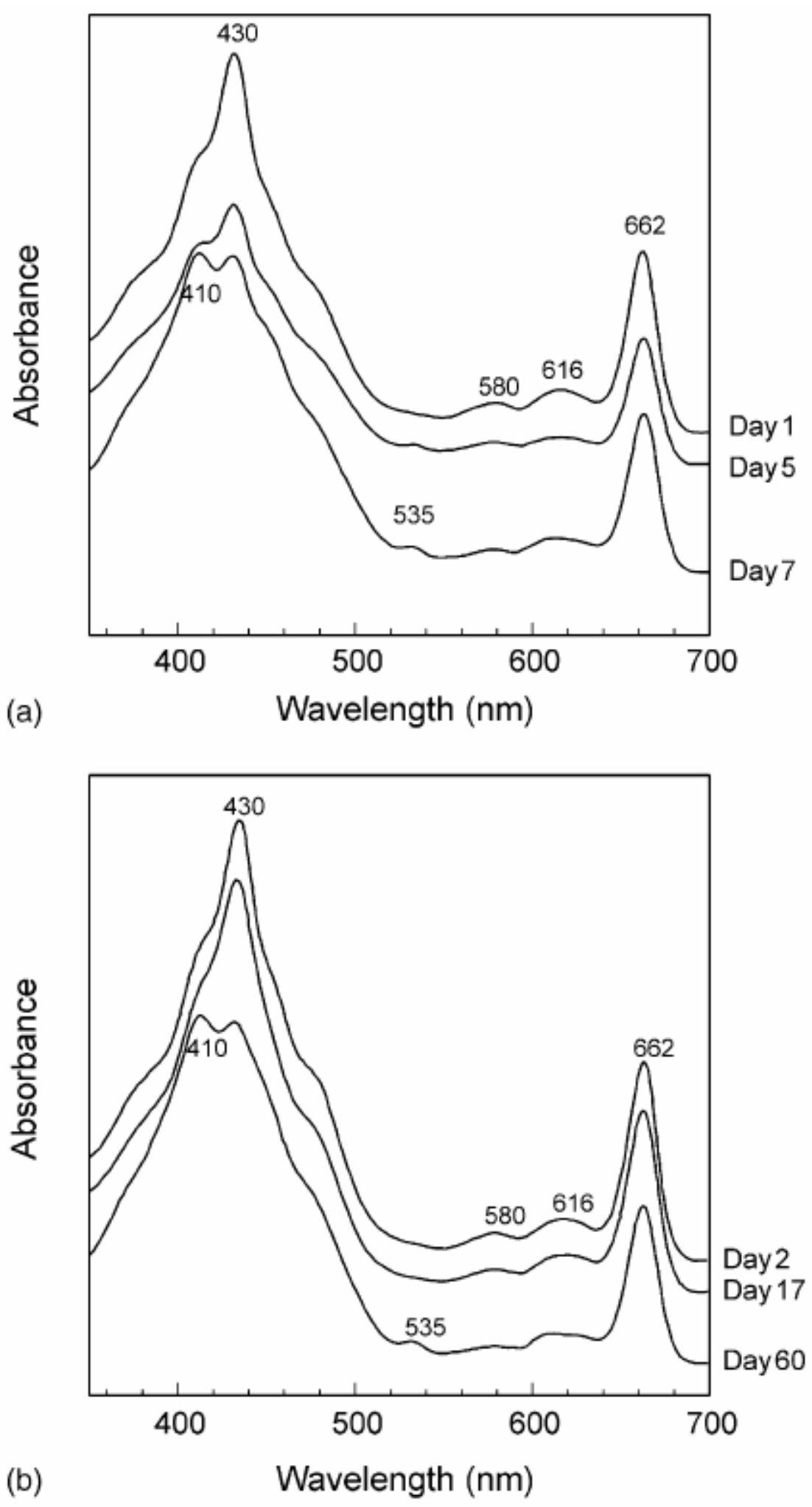
Fig 5. Average instantaneous daily growth rate (DW and AFDW) for oysters fed diets of live or concentrates of Thalassiosira pseudonana. Bars without a common letter are significantly different $(\mathrm{P}<0.05)$. Error bars are \pm 1 s.d. $(\mathrm{n}=4)$.

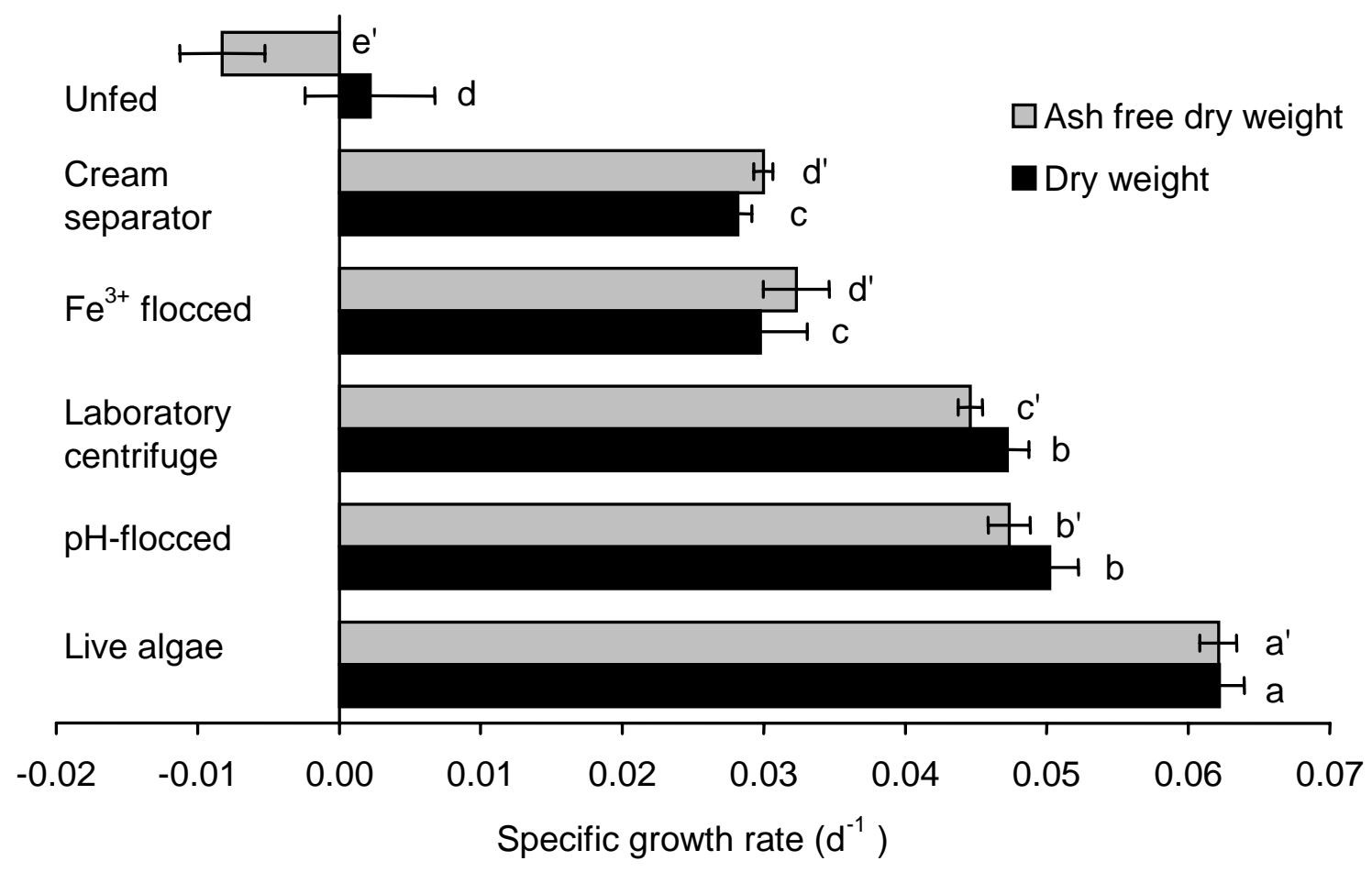


Fig 6. Growth of juvenile Pacific oysters, with or without supplementation of live or concentrated microalgae, expressed as $\%$ increase $\mathrm{DW} \pm 1$ s.d. Bars with a common letter are not significantly different $(\mathrm{P}>0.05)$.

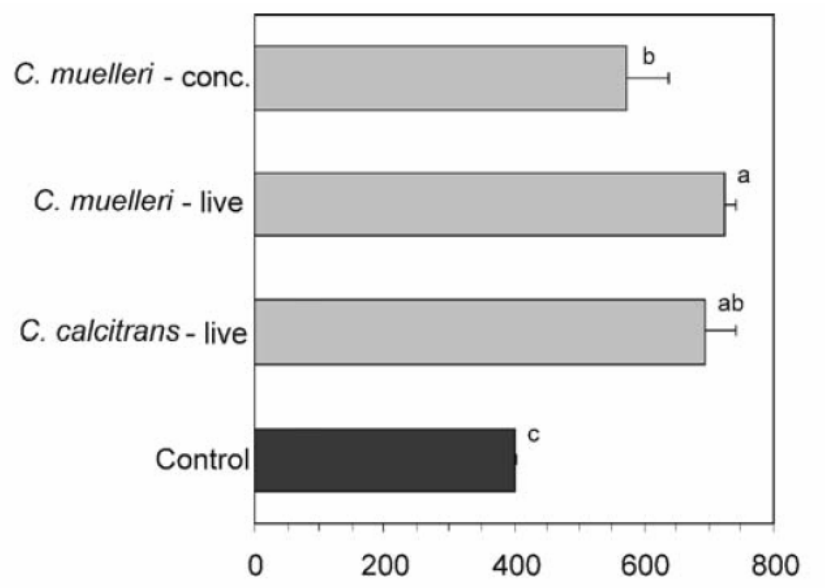

(a)

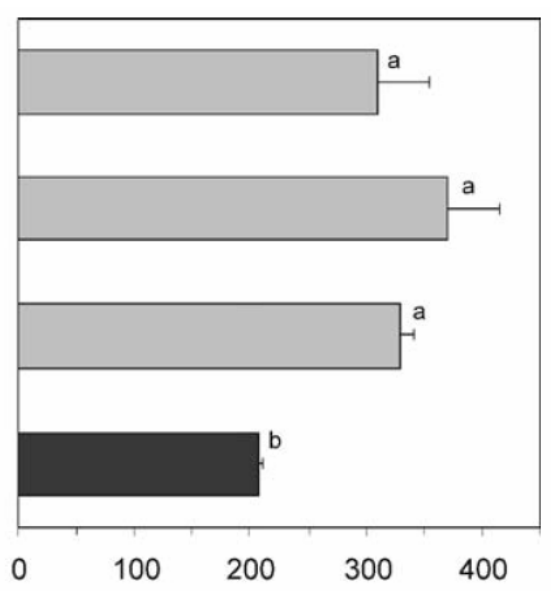

(b) \% increase in scallop DW 